POLIIICAL ECONOM Y RESEARCH INSTIIUIE

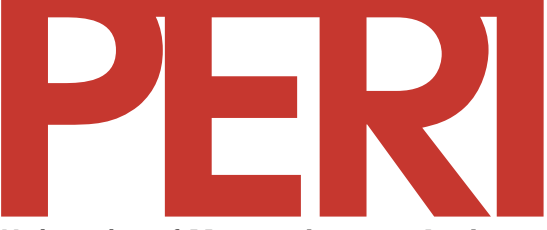

University of Massac husetts Amherst

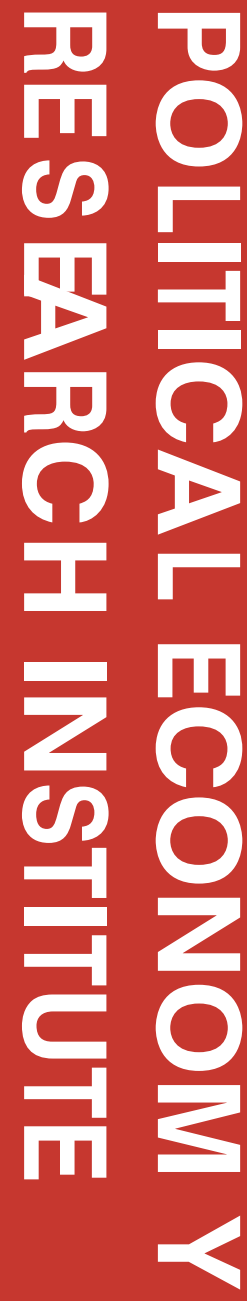

Thomas I. Palley

2005

Forthcoming in the Journal of Contemporary China, Vol. 15 (46), 2006

Gordon Hall

418 N Plea sant St., Suite A

Amherst, MA 01002

Telephone: (413) 545-6355

Facsimile: (413) 545-2921

E-mail: peri@eco ns.umass.edu Website:

http:// www.umass.edu/ peri/

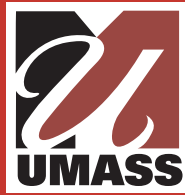


Journal of Contemporary China, Vol. 15 (46), 2006, forthcoming.

\title{
External Contradictions of the Chinese Development Model: Export-led Growth and the Dangers of Global Economic Contraction
}

\begin{abstract}
China's development model faces an external constraint that could cause an economic hard landing. China has become a global manufacturing powerhouse, and its size now renders its export-led growth strategy unsustainable. China relies on the U.S. market, but the scale of its exports is contributing to the massive U.S. trade deficit, creating financial fragility and undermining the U.S. manufacturing sector. These developments could stall the U.S. economy's expansion, in turn triggering a global recession that will embrace China. This is the external constraint.

These considerations suggest China should transition from export-led growth to domestic demand-led growth. This requires growing the economy's demand side as well as its supply-side. To avoid stalling the U.S. economic expansion, which is critical to China's growth, China should significantly revalue its currency as part of a generalized East Asian upward currency revaluation.

Longer term, China should raise wages and improve income distribution. Under export-led growth, higher wages undermine employment. Under domestic demand-led growth, they support it. The challenge is to raise wages in an efficient decentralized manner. History shows that this requires independent democratic trade unions. However, such unions are currently unacceptable to Chinese political leadership. Creating a domestic demand-led growth regime therefore requires solving this political roadblock.
\end{abstract}

Keywords: Export-led growth, domestic demand-led growth

JEL ref.:E01

\author{
Thomas I. Palley \\ Economist \\ Washington, DC 20010 \\ e-mail: mail@thomaspalley.com
}

This version May 2005

\footnotetext{
* Paper presented at a conference on "China-U.S. Relations in the Asia-Pacific Context," co-sponsored by the Graduate School of International Studies, Denver University and the School of International Studies, Peking University, held in Beijing, China, October 2123, 2004.
} 


\section{Limits to China's current development strategy: competing hypotheses}

Over the last twenty years China has experienced an economic development miracle. Its recent success is captured in table 1 which details key economic statistics including the GDP growth rate, level of foreign direct investment (FDI), level of total exports, rate of growth of exports, exports to the U.S., trade surplus with the U.S., global trade surplus, and level of foreign exchange reserve holdings. Over the last five years, both real GDP and exports have grown rapidly, and especially impressive has been China’s continued growth during the global downturn of 2001.

A debate has now opened regarding the sustainability of the Chinese model. Ironically, this debate has been triggered by the recent acceleration in Chinese growth, which exceeded 9 percent in 2003 and 2004. The fear is that rapid growth is being driven by a private investment bubble and excessive misdirected state investment. As a result, China risks rising inflation, and when the bubble pops there could be a damaging hard landing.

This paper offers an alternative interpretation of China’s development model. Like the conventional story described above, it too argues that the current model is unsustainable. However, it is not the "domestic” consequences of over-investment and excessive growth that are the reasons. Instead, the reason is China's "external” impact on the global economy, which threatens to trigger a world recession that will rebound and embrace China.

In effect, there are two competing hypotheses regarding China’s development model. The conventional hypothesis is labeled the "internal contradictions" story, and it emphasizes the domestic financial instability and inflationary consequences of over- 
investment and fixed exchange rates. In Washington D.C. it is associated with the views of Alan Greenspan, Chairman of the Federal Reserve, and economists Morris Goldstein and Nicholas Lardy of the Institute for International Economics. ${ }^{1}$ The alternative hypothesis is labeled the "external contradictions" story. It is rooted in global Keynesianism and emphasizes the deflationary consequences of China's export-led development model. Both hypotheses maintain that China risks a hard economic landing absent policy changes, but they differ regarding the trigger behind the hard landing. ${ }^{2}$

It is easy to conflate these two interpretations as they have important complementarities. Thus, under the external contradictions story, an export slowdown is likely to trigger domestic financial instability as borrowers default on loans and Chinese economic activity contracts. Likewise, the internal contradictions story can have overinvestment concentrated in the export sector. However, the two hypotheses rest on distinct trigger mechanisms. ${ }^{3}$

The balance of the paper is as follows. Section II provides an interpretation of the current Chinese development model. Section III describes the internal contradictions hypothesis and proposed policy remedies. Section IV describes the external contradictions hypothesis. Section V describes the proposed policy remedies for the external contradiction problem. The core challenge is to build China's domestic market, which means addressing China's wage and income distribution problem. This leads into controversial territory since the economic institutions (e,g free democratic trade unions) needed to solve the income distribution problem have political implications that are unacceptable to China’s current political leadership. Section VI concludes the paper.

\section{Interpreting the current Chinese development model}


China’s recent economic record has been one of phenomenal success. Broadly speaking, the Chinese development model aims to reduce the size of the centralized planned economy and increase the size market-based private sector activity. The first step in this transition was taken with the historic 1979 reforms of the agricultural sector. Since then, private sector activity has been allowed to spread more widely by removal of controls on economic activity, and it is also being spread (in limited fashion) by partial privatization of state owned enterprises (SOEs). This spread of market-centered activity has been accompanied by an explicit external and internal capital accumulation strategy. The external accumulation strategy rests on foreign direct investment (FDI) and exportled growth, while the internal strategy rests on use of state-controlled domestic bank credit creation to fund SOEs and infrastructure investment. This development strategy is illustrated in Figure 1.

FDI has served to bring capital goods and high technology into the country, and has been financed by foreign multinational companies (MNCs). The scale of FDI flows is reflected in the fact that China was the world's largest recipient of FDI in 2002, and the total stock of FDI in China exceeded $\$ 500$ billion by the end of $2003 .^{4}$ China is currently the third largest cumulative recipient of FDI, and at current rates of inflow it will soon be the second largest.

In addition to bringing in capital goods and high technology, the construction and operation of foreign-owned plants has also created employment. Particularly important is the fact that FDI has been a form of self-financing development that solves the historic foreign exchange shortage problem. Industrialization calls for importing capital goods from developed economies. Historically, this has imposed a balance of payments 
constraint on growth, and has also led to the accumulation of foreign currency denominated debts. This in turn has exposed countries to financial fragility as the real value of debts can change rapidly due to exchange rate fluctuations. China's FDI-based development model short-circuits this foreign financing problem.

In addition to funding industrialization, FDI has also provided a source of export earnings since a significant portion of MNC output in China is exported. In 2004, MNCs provided 57 percent of total exports, and these exports earnings have provided foreign exchange and balance of payments cover that has ensured external investor confidence. ${ }^{5}$ This export production has been a core element of China's export-led growth strategy. In the absence of a developed domestic consumer market, China has relied on foreign markets - especially the U.S. market - to provide demand for the goods produced by Chinese factories. At the official exchange rate exports constituted approximately $27.5 \%$ of China's GDP in 2003. According to the World Bank, manufacturing represents approximately $44.5 \%$ of China’s GDP. Assuming all exports are manufactured and imported inputs represent one-third of the value of exports, this implies exports equal $41 \%$ of China's manufacturing output.

FDI has also provided advanced technology and capital to China, which combined with China's low wage labor, has made China the low cost global manufacturing leader. With exports booming, foreign MNCs have been willing to continue building new plants in China. On the surface, this has given rise to the anomalous situation in which low income China has been a lender (in the form of its trade surplus) to the high income United States. Normally, it is expected that high-income households save and lend to low-income households. However, there is logic to this situation. Exports and a trade 
surplus (i.e. Chinese savings) are the price that China pays for getting foreign MNCs to invest in China. For the Chinese government this is a deal worth striking, since China gains productive capacity, high technology, and jobs. The foreign exchange from the trade surplus also provides protection against the vagaries of the international economy. ${ }^{6}$

The bottom line is that though FDI is small relative to total Chinese fixed asset accumulation, it occupies a special position of leverage in the Chinese development model. ${ }^{7}$ Much Chinese fixed asset accumulation is public infrastructure capital that yields social returns. FDI yields market returns, transfers technological know-how, and generates export earnings. Moreover, this is done without recourse to foreign borrowing.

The above external accumulation strategy has been complemented by an internal strategy predicated on state-directed domestic bank credit expansion, which finances domestic expenditures in SOEs. The state owned domestic banking system has been used to fund large industrial and infrastructure investment projects, as well as to maintain employment in loss-making SOEs. This has helped support domestic aggregate demand (AD) and also avoided a precipitous collapse of employment in the SOE sector.

The fact that the state owns the banking system means that the state has been able to direct funds in these ways. Lack of alternative financial institutions and investments means that Chinese savers have effectively been forced to finance these state investment activities since savers have few alternatives in which to place their money. Finally, the interest cost of this internal accumulation strategy has been kept down via financial repression - that is keeping interest rates low by policy edict.

\section{The internal contradictions hypothesis}


The above development model has worked remarkably well. However, recently doubts have been expressed about the long run viability of the model. In particular, there are fears that China's rapid growth rate is unsustainable, and is being driven by an asset price bubble and excessive state investment financed with domestic credit creation. In addition, China's large current account (trade) and capital account (FDI) surpluses combined with its fixed exchange rate, have led to increased money supply growth (see table 1). This is because China's central bank has had to provide liquidity in order to prevent the exchange rate from appreciating. As a result, monetary policy has been highly accommodative of the investment boom. The danger is that this will generate even more investment, further asset price increases and accelerating inflation, all of which will eventually end in a hard landing. ${ }^{8}$

This view can be labeled the internal contradictions hypothesis, and it sees China's existing development strategy as running into trouble because of problems internal to the Chinese economy. This internal contradictions hypothesis can be understood with the help of Figure 2. The internal contradictions view focuses on problems in the banking system and corruption, and it also focuses on the domestic inflation consequences of an undervalued real exchange rate. ${ }^{9}$

With regard to the banking system, the internal contradictions view focuses on problems associated with state direction of bank lending and reliance on non-market lending criteria. First, such lending is frequently associated with corruption owing to lack of commercial checks. Second, the absence of commercial lending criteria results in misallocation of resources, with over-building in some sectors and under-building in others. When resources are allocated on market principles, they are directed to sectors 
where there are shortages and returns are highest. When cronyism dominates the allocation process, there can be under-building in sectors with shortages and bottlenecks, and continued over-building in sectors with excess capacity. At the macroeconomic level, this means the Chinese economy may be simultaneously prone to both inflation and deflation - inflation in sectors with bottlenecks and deflation in sectors with excess capacity. Third, the non-commercial credit allocation means that China’s banking system is insolvent and full of non-performing loans (NPLs). Many of the "so-called" investments financed by bank loans are unproductive, and many loans have simply financed SOE operating expenditures.

The internal contradictions view also identifies inflation, caused by an undervalued fixed exchange rate, as a problem. This is classic open economy monetarism. ${ }^{10}$ Maintaining an undervalued exchange rate requires the monetary authority to sell local currency, which expands the domestic money supply leading to domestic inflation and economic distortions that go with higher inflation. ${ }^{11}$

China's policymakers have accepted some of this argument, and have initiated policies aimed at slowing growth and reducing inflationary pressures. Thus, state and local governments have been instructed to cut back on infrastructure investments, banks have been ordered to curtail the expansion of lending, reserve requirements have been raised to drain liquidity from the banking system, and open market sterilization operations have also been used to reduce liquidity. ${ }^{12}$ In October 2004 the official interest rate was also raised a quarter point. Steps are also being taken to partially privatize the banking system by selling off minority stakes. This will raise foreign exchange for the Chinese government, and it is hoped that the introduction of foreign owners will result in 
the adoption of new management practices that put banks on a commercially oriented footing. However, no action has been taken regarding the under-valued exchange rate.

Proponents of the internal contradictions view maintain that these partial reforms are not enough and that more fundamental reforms are needed to avoid a hard landing. ${ }^{13}$ Administrative lending controls are unlikely to be adequate as companies can turn to other unregulated sources of funding, and the central government also has difficulties controlling state government investment spending. Partial privatization of the banking system may also be insufficient to root out existing management and end politically directed bank lending. Finally, failure to revalue the exchange rate means that there will be continued inflationary pressure from increases in the money supply induced by the trade surplus and capital inflows. ${ }^{14}$

Fundamental contradictions or costly frictions?

There is substance to the internal contradictions hypothesis. However, the key question is whether these problems constitute a "fundamental contradiction” within the Chinese development model or whether they are just "costly frictions.” This paper maintains that they are costly frictions rather than fundamental contradictions. That is they impose large costs on the Chinese economy, and China would be better off if they were remedied. However, failure to do so will not force a hard landing.

The current misallocation of credit results in sub-optimal use of resources. However, as long as China maintains its existing capital controls, the system can continue. This is because Chinese depositors have nowhere else to place their money, and this closed nature of the domestic financial system protects against bank runs. As long as the system remains closed, the NPL problem can be dealt with by periodic bank re- 
capitalizations financed by the central bank - which is similar to the way the U.S. dealt with its saving and loan crisis through the Resolution Trust Corporation.

As currently configured, the financial system is stable even though it is inefficient. It only risks becoming unstable when capital controls are removed or when it is opened up to foreign competition. If capital controls are removed, Chinese depositors will be able to shift money outside the system. Given their existing limited international portfolio diversification, future political uncertainties regarding property rights in China, and the questionable status of China's banking system, depositors would almost certainly rush for the exits and precipitate a financial crisis. Similarly, if foreign commercial banks are allowed to operate independently in China, there will likely be a move out of Chinese banks into foreign owned banks, and this would also quickly expose the failings of domestic banks. These considerations suggest China should avoid opening its capital account, and they also suggest China will be reluctant to meet its WTO commitment to allow foreign financial competition. ${ }^{15}$

Regarding the undervalued exchange rate and current account surplus, the internal contradictions view emphasizes the accelerating inflation danger of maintaining an undervalued fixed exchange rate. Such analysis represents a form of monetarist thinking. An inflation danger does exist, but the link between money supply expansion and inflation is subject to long and uncertain lags. Moreover, inflation can be suppressed through such measures as increased bank reserve requirements or sterilized open market operations in which the central bank sells bonds and drains excess money from the financial system. If inflation were the only problem associated with an under-valued exchange rate, it would be an irritation but not a fundamental systemic contradiction. 


\section{The external contradictions hypothesis: limits to export-led growth}

The previous section argued that the internal contradictions hypothesis does not stand up to scrutiny. While there are major internal inefficiencies in the current Chinese development model, these inefficiencies are costly frictions rather than contradictions. If nothing is done about them, Chinese economic welfare will be lower but they will not pull down the system. Indeed, if modestly faster inflation were the only cost to an undervalued exchange rate, then Chinese policymakers would be well advised to stick with an undervalued exchange rate because of the other benefits under-valuation yields.

This leads to the external contradictions story. In terms of Figure 2, the focus is the far right bottom box. The argument is that China's existing strategy is fundamentally flawed owing to its reliance on export-led growth powered, principally, by the U.S. market. ${ }^{16}$ The reason for this contradiction is that China has become such a global manufacturing powerhouse that it is now driving the massive U.S. trade deficit and undermining the U.S. manufacturing sector, in turn threatening the viability of its major customer. In addition, China is also putting pressure on the European Union's manufacturing sector, slowing economic growth in that region.

Table 2 provides data on China's impact on the U.S. trade deficit. Excluding the deficit with OPEC countries, which is driven by special oil price factors, the overall U.S. goods trade deficit was $\$ 579.3$ billion in 2004. Excluding OPEC and China, the overall deficit was $\$ 417.3$ billion. The bilateral deficit with China was $\$ 162.0$ billion, representing 38.8\% of the U.S. deficit with all non-OPEC countries. In 2004 the deficit excluding OPEC and China increased by $\$ 60.1$ billion; the bilateral China deficit increased by $\$ 37.9$ billion, equal to $63.1 \%$ of the increase in the non-OPEC non-China 
deficit. In growth terms, the bilateral China deficit grew 30.5 percent, while the nonOPEC non-China deficit grew 16.8 percent. Moreover, these developments continue a trend that has seen China's share of the U.S. trade deficit steadily rise since 1999.

The trade deficit threatens to become a source of financial instability. More importantly, the deficit is contributing to the problems in manufacturing that are hindering a robust investment-led recovery. There are two ways in which the deficit has hindered recovery. First, the deficit drains spending out of the U.S. economy so that jobs are lost or are created offshore instead of at home. Using an input-output methodology that estimates the labor content embodied in the deficit, Scott estimates that the U.S. trade deficit with China in 2003 embodied 1,339,300 lost job opportunities. ${ }^{17}$ Using Scott's job calculations and assuming the composition of trade remained unchanged in 2004, the 2004 trade deficit with China of $\$ 162$ billion represents 1,808,055 lost job opportunities. ${ }^{18}$ Second, China adversely impacts investment spending through a range of channels. The draining of demand via the trade deficit creates excess capacity, which reduces demand for new capital. The undervaluation of China's currency makes production in China cheaper, and this encourages firms to both shift existing facilities and build new facilities in China. These shift effects have been documented by Bronfenbrenner and Luce. ${ }^{19}$ Undervaluation also reduces profitability of U.S. manufacturing and this reduces investment spending. ${ }^{20}$ The U.S. economy is of course a huge economy and these China effects are small in terms of total investment. However, China is likely exerting a chilling effect at the margin of manufacturing investment, and it is this margin where the recessionary impacts of investment decline have been felt and continue to be felt. ${ }^{21}$ 
Together, these employment and investment effects risk tipping the U.S. economy back into recession after a stultified expansion. ${ }^{22}$ If this happens it will have significant adverse consequences for the Chinese economy and the global economy since the U.S. economy has been the main engine of demand growth keeping the world economy flying. ${ }^{23}$ The contradiction in the Chinese development model is that China's success threatens to undermine the U.S. economy, which has provided the demand fuelling that success. It is for this reason that China needs to replace its export-led growth strategy with a domestic demand-led growth strategy.

Chinese economic statistics provide clear evidence of export-led growth. Table 1 shows that nominal GDP grew at an average annual rate of 9.2\% between 2000 and 2003 while exports grew at an average annual rate of $22.9 \%$ over the same period. Moreover, this difference increased in 2004 when nominal GDP increased 9.5\% while exports surged $35.4 \%$. The critical feature of export-led growth is reliance on exports as a source of final demand. Exports have clearly been growing faster than GDP, indicating that exports are becoming an increasingly important source of final demand. Moreover, this export growth is from a non-trivial base. GDP in 2004 was 13, 651 billion RMB, which translates to $\$ 1,645$ billion using an exchange rate of 8.30 RMB per dollar. Exports in 2004 were $\$ 593.4$ billion, equal to 36 percent of GDP. Moreover, export demand comes from outside the economic system and therefore constitutes an injection of demand into the Chinese economy. This demand stimulates production and employment, which in turn generates additional demand from spending out of induced incomes. The contribution of exports, both directly and indirectly through induced demand, is therefore very large. 
The underlying contradiction operates through the U.S. trade deficit, and fixing this deficit undoubtedly requires action by more countries than just China. ${ }^{24}$ That said, China is the single largest contributor to the deficit, accounting for approximately 30 percent of the non-OPEC deficit. Moreover, its share is growing. The implication is that the U.S. trade deficit cannot be fixed without China’s cooperation.

Other East Asian countries (Japan, South Korea and Taiwan) are also large contributors to the trade deficit, and they will also need to revalue their currencies upward if the U.S. trade balance is to be put on a sustainable balance. However, there is a first mover problem. If they revalue their currencies upward but China does not, they will lose competitive advantage and could just transfer market share to Chinese exports with no benefit to the U.S. economy. To a lesser degree, if China revalues and they do not there could be a similar market share transfer effect. This points to the need for a coordinated East Asian currency adjustment, but China must play a lead role as it is the largest contributor to the deficit and the regional low cost producer.

As of the moment, China's adverse impact has not derailed the U.S. economy owing to continued debt financed spending by U.S. households. China has therefore been able to continue to grow despite the weak U.S. recovery from recession. However, the U.S. trade deficit, the erosion of the U.S. manufacturing base, the increase in U.S. household indebtedness, and the weak jobs recovery are collectively undermining the structural strength of the U.S. economy. Though the economy looks strong, there is reason to believe that it is increasingly fragile - akin to a "Wiley Coyote" economy running on thinner and thinner air. The recovery has been financed by asset price appreciation, especially real estate, which has supported increased borrowing that has 
funded consumer spending. Owing to the trade deficit, this spending has not generated a robust jobs recovery and the income to pay back these borrowings, yet indebtedness has increased. The danger is that the U.S. economy could stall, and the over-hang of consumer debt could then drive the economy into recession. With private sector balance sheets strained by debt taken on at current low interest rates and not open to refinancing, the U.S. would not have recourse to another recovery driven by consumer borrowing. Instead, debt burdens will deepen a slump. And if asset prices fall, the downturn could be amplified by household wealth erosion and the creation of negative homeowner equity that causes the housing market to seize up.

This is a difficult scenario for Chinese policymakers to grasp since the damage to China is indirect, operating via recession in the United States. China's trade surplus has been viewed as a sign of success and as critical to the Chinese development model. Now, Chinese policymakers need to change their thinking and recognize that the trade surplus has become a fatal flaw in the Chinese model. If the U.S. undergoes a consumptiondriven recession (as against an investment-driven recession), China risks catching economic pneumonia. Moreover, with much of the global economy also relying on the U.S. market, a U.S. recession will injure the global economy which will further hurt China by lowering global demand for Chinese exports.

Finally, China's export-led growth model is not just a problem for the United States. It is also a problem for other developing countries that compete with China in world markets. Moreover, this is likely to worsen with the ending of the multi-fiber agreement (MFA) governing textile trade as China stands to increase its share of global 
textile exports at the expense of other developing countries, creating employment and balance of payments problems for these countries. ${ }^{25}$

China also poses an increasing problem for the European economy. First, Europe has a large textile industry that stands to be adversely impacted by the end of the MFA. Second, Europe is being adversely impacted by the appreciation of the euro against the renminbi. With the renminbi is pegged to the dollar, appreciation of the euro against the dollar implies an appreciation of the euro against the renminbi. Europe gained vis-à-vis China when the euro was weak: it loses when the euro is strong.

The bottom line is that China has become a global manufacturing powerhouse on the back of its FDI export-led growth development model, and its manufacturing size is now exerting huge strains on the entire global economy. Thus far, China has been able to free-ride on global aggregate demand. The strategy worked when China was small: it cannot work now that China is so large. In effect, China’s free-riding has become an international public bad. China’s policymakers must recognize the necessity of adjusting their development model. However, it is difficult to persuade policymakers that adjustment is needed since the model works as long as the U.S. plays the role of buyer of last resort and accepts body blows to its manufacturing base. ${ }^{26}$ The piper will only have to be paid when this role is exhausted. ${ }^{27}$

\section{Beyond export-led growth: developing the demand side of the Chinese economy}

The solution to the contradictions posed by China's emergence as a global export powerhouse is to build a robust internal Chinese market that supports domestic demandled growth. This requires developing structures, institutions, and economic relations that generate sustained stable internal demand growth. This is an enormous task and one that 
is unrecognized in conventional development economics, which focuses exclusively on the supply-side of the economy. Developing the demand side of an economy is key to becoming a developed country status, yet it is a task that has received negligible attention. $^{28}$

Moving from the current model to the new model requires a short- and long-term strategy. The short-term strategy must address the fact that China is exerting destabilizing deflationary pressures on the global economy, that if not corrected risk triggering a global recession. The long-term strategy must wean China from export-led growth to domestic demand-led growth. This two-part adjustment strategy is shown in figure 3. Short term strategy: coordinated East Asian currency revaluation

In the immediate short-term China must significantly revalue its exchange rate against the U.S. dollar by between 15 and 40 percent. ${ }^{29}$ This appreciation should be conducted as part of a broader coordinated move that has the exchange rates of other trade surplus East Asian economies (Japan, South Korea, Taiwan, Singapore, and Malaysia) also adjusting upward. Coordination is essential since all are contributing to the problem, and adjustment by just one country alone will cause it to lose competitiveness and suffer economic injury without fully correcting the problem. This is because its export production would tend to migrate to those countries that retained under-valued exchange rates so that the U.S. trade deficit would be only modestly improved. Coordination is therefore essential for a rapid effective correction of the U.S. trade deficit, which is the immediate threat to the U.S. and global economy. That said, China should lead this coordinated adjustment as it has by far the largest trade surplus 
with the U.S., and that surplus is growing rapidly. Once China has signaled its acceptance of currency adjustment, others will do so voluntarily or can be easily persuaded to do so.

Exchange rate revaluation will impose costs on China, which will experience a decline in demand for its exports. This decline will reduce demand for Chinese production and could slow growth. Why then should China make such an adjustment? The reason is that failure to do so risks a deep U.S. economic contraction that will seriously harm China, and it is better to take less costly pre-emptive action. Moreover, now is a propitious time to make such an adjustment, and it will also yield several benefits for China. With regard to timing, China has a large balance of payments surplus with the U.S. and the global economy. This means that it can accommodate a revaluation that appreciates the real exchange rate without being plunged into a balance of payments crisis. Second, revaluation can help China address the current threat of accelerating inflation that poses both economic and political threats. ${ }^{30}$ Third, revaluation will improve China's terms of trade, making imports cheaper. This will benefit the average Chinese consumer. It will also lower the cost of imported inputs, partially offsetting the adverse competitive impact that revaluation has on Chinese export and import-competing industries.

In addition to revaluing East Asia’s currencies, there is need for a new managed global exchange rate system analogous to Bretton Woods. Simply revaluing currencies will not bring about the changes in business behavior needed to put the U.S. economy back on a robust path of sustained growth. If business is to retain plants and make new investments in U.S. manufacturing, businessmen need to have confidence that the new exchange rates will hold for a significant period of time. If they feel that the revaluation 
will reverse in the near future they will not alter their business plans. Investment and production will therefore not return the U.S., and the recovery will remain fragile. On this score, U.S. policymakers deserve criticism for failing to recognize this problem. In a knee-jerk reaction to earlier problems with fixed exchange rates in the 1990s, they are now pushing floating rates for all. This is inappropriate policy for a world integrated by trade and financial capital flow, and in which production and investment are highly mobile. A new system of managed exchange rates is what is called for. ${ }^{31}$

Long term strategy: domestic demand-led growth

With regard to long-term strategy, there is need for a dramatic recalibration of China's development policy. Economic theory and policy has traditionally focused on expansion of the supply-side. This is the focus of the export-led growth paradigm which emphasizes becoming internationally competitive and relying on export markets - that are outside the control of developing country policymakers -- to provide demand and absorb increases in production. China has followed this paradigm for the last fifteen years, growing its export supply-side through FDI and relying on demand from export markets. Now, China must start to develop its own demand side.

This is a difficult challenge. It is also one that economics has traditionally said little about because the main body of development economics ignores the demand-side. ${ }^{32}$ The claim is that policymakers need only focus on the supply-side, and demand will automatically be forthcoming. Consequently, little attention has been devoted to the challenge of developing the demand side. Yet, successfully developing the demand side is the distinguishing hallmark between developed and developing countries. 
Keynesian economics does emphasize demand considerations, but it operates in the context of mature market economies in which the process of demand generation is established. For Keynesians, shortages of demand can be remedied by government policies (lower interest rates and taxes) that stimulate private sector demand or by direct government spending. However, these policies ameliorate temporary failures in an established demand generation process. In developing countries the challenge is to build the demand generation process. Application of Keynesian policies to stimulate private sector demand in developing countries tends to contribute to excessive government deficits and promote an excessively large government sector. Increased government spending adds to demand but it increases deficits, and it also does little to generate "market" incomes that are the basis of a sustainable demand growth generation process.

China's challenge is to develop sustainable growing sources of non-inflationary domestic purchasing power. This means attending to both the investment allocation process and the income allocation process. The former is critical to ensure that resources are efficiently allocated, earn an adequate rate of return and add to needed productive capacity. The latter is critical to ensure that domestic demand is forthcoming to absorb increased output. Income must be placed in the hands of Chinese consumers if robust consumer markets are to develop. The challenge is to deliver this income in an efficient equitable manner that maintains economic incentives and is also consistent with aggregate production so as to avoid inflation.

Reforming the investment allocation process

Chinese investment spending relies significantly on a combination of FDI and public investment funded through the government owned banking system. This reliance 
on public direction of the banking system has proven inefficient. With capital widely allocated on the basis of non-market criteria, investments are frequently unable to generate adequate market returns so that China's banks are beset by massive nonperforming loans. From a macroeconomic standpoint, the failure to use market signals means that investment fails to remedy bottlenecks and can aggravate problems of surplus capacity. This is because politically favored sectors continue to receive investment funds even if they have surplus capacity, while out of favor sectors are denied funds even if they have bottlenecks. This misallocation means that inflation and deflation can coexist, with bottleneck sectors experiencing inflation while those with over-investment experience deflation.

Reform of the banking system is critical to improving China's capital allocation process, and it is also necessary to create efficient consumer credit and mortgage markets that can support demand generation in the household sector. Successful banking sector reform will raise productivity and output growth by improving the investment allocation process. At the same time, by strengthening consumption and housing demand, it will stimulate new investment spending to provide for those increased demand.

Privatization of China's banking system is key to reform, and some privatization is already underway. The Chinese model is one of partial privatization - selling off minority ownership stakes. The hope is to inject private sector management techniques into the banking system, thereby transforming it so that loans are made on the basis of borrower credit-worthiness. Selling off state-owned banks will also raise considerable sums for the Chinese state, while retaining a majority stake means that the Chinese government will also benefit from improvements in bank profitability. 
However, there are risks with this strategy. First, foreign investors may be blocked from making needed reforms to lending and organizational practice because they are minority shareholders. Second, reform of the banking system will necessitate reform of government finances. This is because the banking system is currently used to dole out subsidies to failing SEOs and to direct capital to politically favored clients. If the banking system is made to operate according to commercial lending practices, such subsidies will no longer be available. Government can still use the banking system, but only as a payments system for making disbursements and collecting taxes. If China is unable to reform its public finances, this will likely sabotage banking sector reform. This points to a significant time consistency dangers in the current reform process. Having sold minority stakes in the banking system, Chinese policymakers may be unwilling to follow through and adopt real reform of banking practices.

Lastly, as China modernizes its banking and financial system it must simultaneously develop a framework for conducting effective financial policy. If financial markets are to contribute fully to the demand generation process they must be stable, free of corruption, and deserving of investors' confidence. They should also facilitate government counter-cyclical economic stabilization policy. China must therefore develop (i) deep bond markets that allow for open market monetary operations that control short-term interest rates, (ii) transparent and fair central bank discount window policy, (iii) transparent and effective accounting requirements and prudential regulation, and (iv) policy instruments of quantitative control - such as margin requirements, reserve requirements on capital inflows, and asset based reserved requirements - that can help mitigate pro-cyclical tendencies in financial markets. ${ }^{33}$ 
Income distribution: free trade unions and minimum wages

Banking and financial market reform is a needed component of a domestic demand-led growth strategy. However, a greater challenge is developing an appropriate system of household income distribution that supports domestic consumer markets. Investment spending is an important source of demand, but the output generated by investments must find buyers or investment will cease. Likewise, public sector investment can be an important source of demand, but private sector output and income must grow overtime or else the government sector will come to dominate with negative consequences.

With a population of 1.3 billion people China has an enormous potential domestic market. The challenge is to distribute income in a decentralized equitable fashion that leaves work and production incentives intact. The conventional view is that markets automatically take care of the problem by paying workers what they are worth and that all income is spent thereby generating the demand for output produced. In effect, the problem is assumed away. Indeed, to intervene and raise wages to increase demand would be to cause unemployment by making labor too expensive.

This conventional logic contrasts with Keynesian economics, which identifies the economic problem as one of ensuring a level of aggregate demand consistent with full capacity utilization. Moreover, the level of aggregate demand (AD) is affected by the distribution of income, with worsened income distribution lowering aggregate demand because of the higher propensity to save among higher income households. From a Keynesian perspective, market forces do not automatically generate an appropriate level of AD. Demand can be too low because of lack of confidence among economic agents 
that lowers investment and consumption spending. It can also be too low because the distribution of income is skewed excessively toward upper income groups. ${ }^{34}$

The importance of income distribution for $\mathrm{AD}$ and full employment means that labor markets are of critical significance. Labor markets determine wages, and wages impact income distribution and AD. From a Keynesian perspective, the problem is that bargaining power can be highly skewed leading to wages that are too low. This problem is particularly acute in developing countries. Trade unions are a vital economic mechanism for rectifying imbalances of bargaining power and they can therefore help achieve an appropriate distribution of income. Palley presents evidence to this effect. ${ }^{35}$ Cross-country data for a panel of seventy-nine countries from the second half of the 1980s and the first half of the 1990s shows that improved freedom of association in labor markets is associated with improved income distribution and higher wages.

Rather than being a market distortion as described in neo-classical economics, trade unions may correct market failure associated with imbalanced bargaining power. Viewed in this light, trade unions are the market friendly approach to correcting labor market failure because unions set wages in a decentralized fashion. Though wages are set by collective bargaining, wages can differ across firms with unions in more efficient firms bargaining higher wages than those at less efficient firms. This contrasts with a government edict approach to wage setting.

This suggests that a key priority for China should be to develop a system of democratic trade unions that freely bargain wages. Just as China is reforming its corporate governance and financial system, so too it must embrace labor market reform centered on democratic trade unions because this is the market centered way of 
establishing an income distribution that can support a consumer society. Outside of Western Europe, only the U.S., Canada, Japan, South Korea, Australia and New Zealand have successfully made the transformation to mature developed market economies. In all cases this transformation coincided with the development of effective domestic trade unions.

The encouragement of free trade unions should also be supported by effectively enforced minimum wage legislation. Just as trade unions have helped developed countries make the move to demand-led growth, so too have minimum wages. China is a continental economy in which regions differ dramatically by level of development. This suggests the need for a refined system of minimum wages in which minimum wages are set on a regional basis and take account of regional differences in living costs. Overtime, as development spreads and backward regions catch up, these settings can be adjusted with the ultimate goal being a uniform national minimum wage.

Lastly, these wage-targeted labor market reforms should be paired with the development of a social safety net that provides insurance to households. This will increase households' sense of confidence and security, thereby diminishing the need for precautionary saving and enabling households to spend more on consumption. Can China afford higher wage costs?

Finally, there is the issue of costs. As long as China follows an export-led growth strategy, production costs will be paramount. The dynamic of export-led growth, with its focus on international markets, forces countries to try and ever lower costs to gain international competitive advantage. This makes for systemic downward pressure on wages, and these pressures are needed to keep export-led growth viable. 
A domestic demand-led growth paradigm removes this pressure. Now, higher wages become a source of demand and therefore strengthen the viability of employment. Capital must still earn an adequate return to pay for itself and entice new investment, but moderately higher wages now strengthen the system rather than undercutting it.

\section{Summation}

China's current development model faces an external constraint that risks causing a hard landing in China and the global economy. China has become a manufacturer of global scale, rendering its export-led growth strategy unsustainable. China relies on the U.S. market, but the scale of its exports is undermining U.S. manufacturing and risks tipping the U.S. economy back into recession, which would then trigger a Chinese and global recession. This is the external constraint.

China should shift from export-led growth to domestic demand-led growth. This requires a focus on growing the demand side of the economy, not just the supply-side. In the immediate short-term there is need for a significant currency revaluation to avoid stalling the U.S. economic expansion. Longer term, China must move to raise wages and improve income distribution. In an export-led growth system, higher wages undermine growth. In a domestic demand-led growth system, they support it. The challenge is to raise wages in an efficient decentralized manner, which calls for developing independent democratic trade. However, independent unions are unacceptable to the current Chinese political leadership. Moving China on to a path of domestic demand-led growth therefore requires solving this political roadblock. 


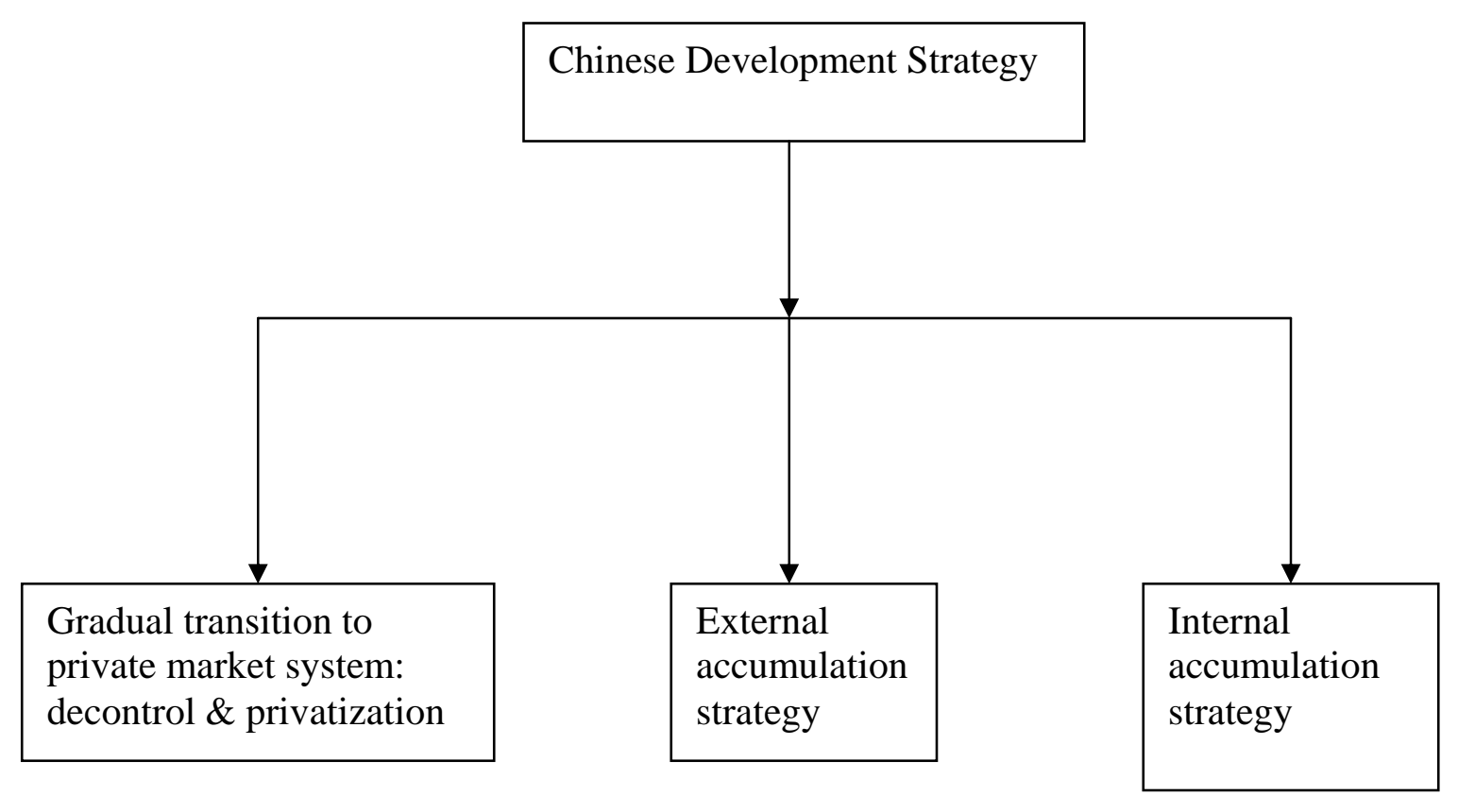

Figure 1. Overview of the Chinese development strategy. 


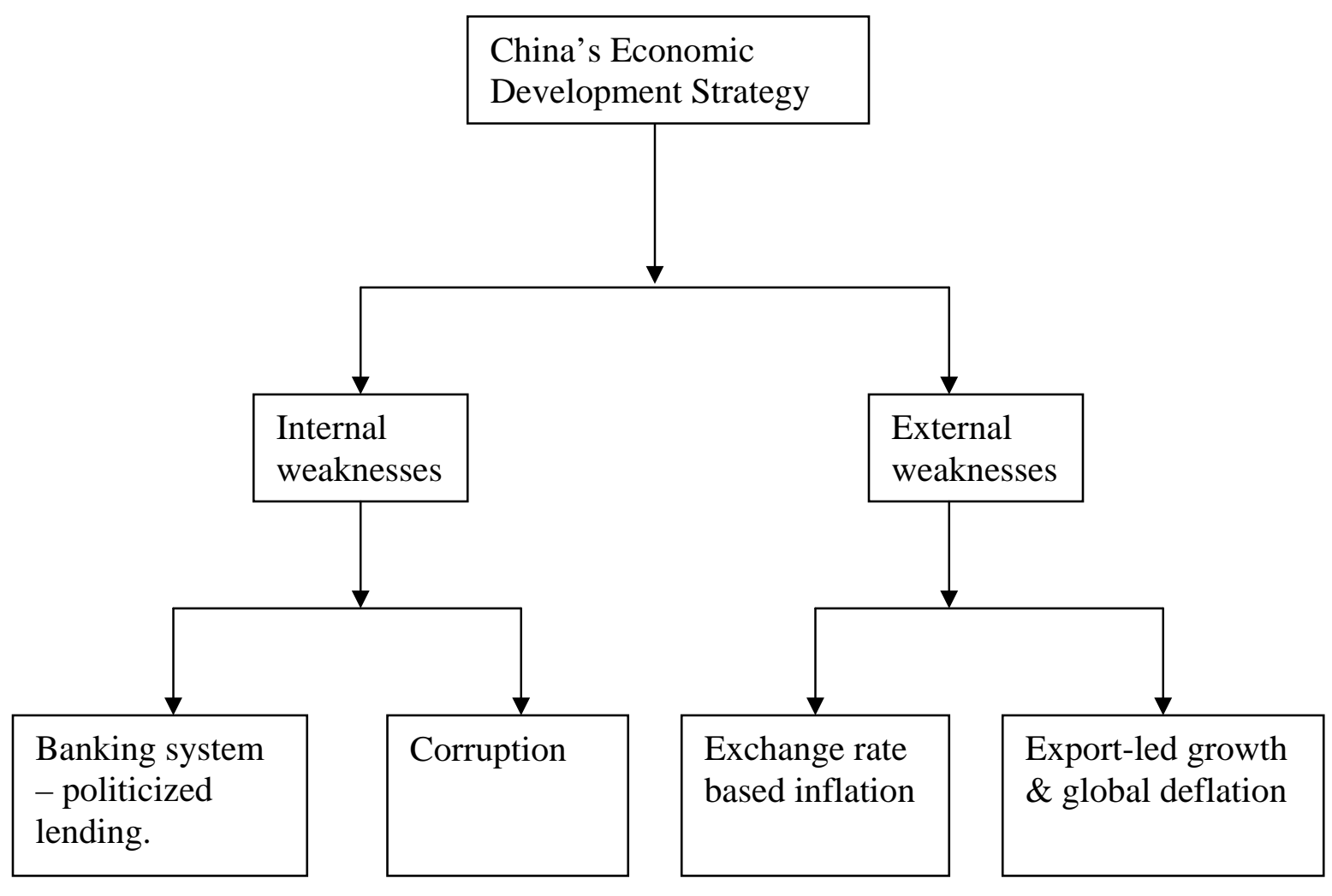

Figure 2. Weaknesses in the existing Chinese economic development model. 


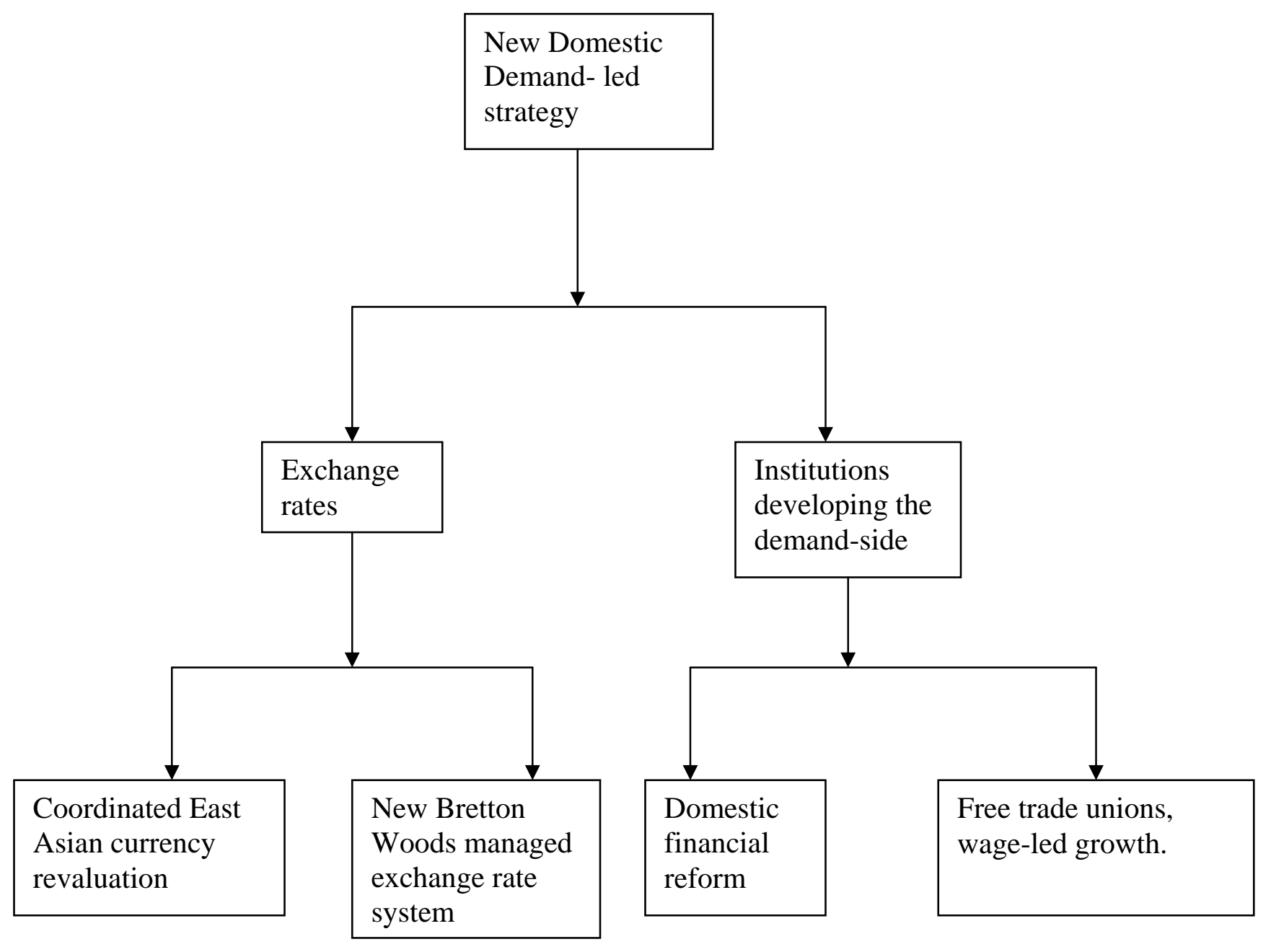

Figure 3. Domestic demand-led growth strategy. 


\begin{tabular}{|l|l|l|l|l|l|}
\hline & $\mathbf{1 9 9 9}$ & $\mathbf{2 0 0 0}$ & $\mathbf{2 0 0 1}$ & $\mathbf{2 0 0 2}$ & $\mathbf{2 0 0 3}$ \\
\hline Nominal GDP (RMB billions) & 8,206 & 8,947 & 9,731 & 10,479 & 11,669 \\
\hline Change nominal GDP (\%) & 4.7 & 9.0 & 8.8 & 7.7 & 11.4 \\
\hline Real GDP growth (\%) & 7.1 & 8.0 & 7.5 & 8.0 & 9.1 \\
\hline FDI - utilized (\$ billions) & 40.3 & 40.7 & 46.9 & 52.7 & 53.5 \\
\hline China's exports (\$ billions) - Chinese data & 194.9 & 249.2 & 266.2 & 325.6 & 438.4 \\
\hline \% change in China's exports & 6.1 & 27.8 & 6.8 & 22.3 & 34.6 \\
\hline China's trade surplus with the U.S.: & & & & & \\
\hline - Chinese data (\$ billions) & 23.5 & 30.9 & 29.4 & 44.1 & 60.3 \\
\hline - U.S. data (\$ billions) & 68.9 & 84.2 & 84.1 & 104.2 & 124.9 \\
\hline China's global trade surplus: & & & & & \\
\hline - Chinese data (\$ billions) & 37.7 & 35.4 & 35.3 & 45.1 & \\
\hline - 43 partner data (\$ billions) & 140.4 & 171.6 & 170.3 & 189.9 & \\
\hline FX Reserves (\$ billions) & 154.7 & 165.6 & 212.2 & 286.4 & 403.3 \\
\hline \% Money supply (M2) growth & 14.7 & 12.3 & 14.4 & 16.8 & 19.6 \\
\hline
\end{tabular}

Table 1. Key statistics on the Chinese economy. Trade surplus data are provided by the Fair Currency Alliance, Washington, D.C., Brief No. 1, June 10, 2004. All other data are from the U.S.-China Business Council, www.uschina.org/statistics/economy.html. 


\begin{tabular}{|c|c|c|c|c|c|}
\hline & $\begin{array}{l}2004 \text { Goods } \\
\text { Trade Balance } \\
\text { (\$ billions) } \\
\end{array}$ & $\begin{array}{l}\text { Percent } \\
\text { share }\end{array}$ & $\begin{array}{l}2003 \quad \text { Goods } \\
\text { Trade Balance } \\
\text { (\$ billions) }\end{array}$ & $\begin{array}{l}\text { Percent } \\
\text { share }\end{array}$ & $\begin{array}{l}\text { Percent } \\
\text { Change } \\
\text { 2003-4 } \\
\end{array}$ \\
\hline Total (census basis) & $-\$ 651.5$ & $100.0 \%$ & $-\$ 532.4$ & $100.0 \%$ & $22.4 \%$ \\
\hline Total $x$-OPEC & $-\$ 579.3$ & & $-\$ 481.3$ & & 20.4 \\
\hline Total x-OPEC \& China & $-\$ 417.3$ & & $-\$ 357.2$ & & 16.8 \\
\hline North America & -110.8 & 17.0 & -92.3 & 17.3 & 20.0 \\
\hline Canada & -65.8 & 10.1 & -51.7 & 9.7 & 27.3 \\
\hline México & -45.1 & 6.9 & -40.6 & 7.6 & 11.1 \\
\hline Western Europe & -114.1 & 17.5 & -100.3 & 18.8 & 13.8 \\
\hline Euro area & -82.9 & 12.7 & -74.1 & 13.9 & 11.9 \\
\hline Pacific Rim & -282.5 & 43.4 & -230.5 & 43.3 & 22.6 \\
\hline Japan & -75.2 & 11.5 & -66.0 & 12.4 & 13.9 \\
\hline China & -162.0 & 24.9 & -124.1 & 23.3 & 30.5 \\
\hline OPEC & -71.9 & 11.0 & -51.1 & 9.6 & 40.7 \\
\hline Rest of the World & -72.2 & 11.1 & -58.2 & 10.9 & 24.1 \\
\hline
\end{tabular}

Table 2. Regional composition of the U.S. goods trade deficit. Source: United States Department of Commerce and author's calculations.

\footnotetext{
${ }^{1}$ Alan Greenspan, Remarks before the World Affairs Council of Greater Dallas, Dallas, Texas, December 11, 2003; Goldstein, M., Adjusting China's Exchange Rate Policies, Institute for International Economics, Washington, D.C., 2004. Goldstein, M., and N. Lardy, Don't hail China's soft landing too soon, Financial Times, Wednesday October 6, 2004.

${ }^{2}$ The external contradictions hypothesis does not deny the significance of the problems identified by the internal contradictions hypothesis. China's economy would be greatly strengthened by remedying these internal problems. However, these internal problems are not core contradictions. Fixing them will improve Chinese economic performance, but failure to do so will not cause the model to collapse. That will only happen if China fails to address the external contradictions inherent in the current development model. ${ }^{3}$ Since delivering this paper (October 2004) the external contradictions story has begun to surface on Wall Street. Stephen Roach writes in the Financial Times (Friday April 22, 2005, p.15), "In China the name of the game is exports. China's biggest export market is the U.S., absorbing fully one-third of its overseas shipments in 2004."”

${ }^{4}$ UNCTAD, Country fact sheet: China, World Investment Report, 2004.

${ }^{5}$ Hong Kong Trade Development Council, www.tdctrade.com/main/china.htm.

${ }^{6}$ The idea that developing countries should run trade deficits for extended periods of time while they develop belongs to the earlier import-substitution development paradigm. The new FDI - export-led growth paradigm has developing countries run surpluses along the development path. Producing cheap exports is the way to attract FDI, which builds the supply-side; demand is provided by export markets rather than domestic markets.

${ }^{7}$ In 2004 total Chinese fixed asset accumulation was 5,862 billion RMB. Total utilized FDI was $\$ 60.6$ billion, which translates to 503 billion RMB using an exchange rate of 8.30 RMB per dollar. That implies FDI was $8.6 \%$ of total, fixed asset accumulation. Data are from the Hong Kong Trade \& Development Council, www.tdctrade.com/main/china.htm.

${ }^{8}$ Goldstein, M., and N. Lardy, op. cit.

${ }^{9}$ Greenspan, op.cit.; Goldstein, op.cit.; Rajan, R., and A. Subramanian, Exchange Rate Flexibility is in Asia' Interest, Financial Times, Monday September 27, 2004. The article by Rajan and Subramanian is indicative of the International Monetary Fund's (IMF) thinking on the China question. The IMF accepts the
} 
internal contradictions hypothesis, and has sought to push China to adopt exchange rate flexibility on the grounds that it would facilitate management of the Chinese economy and avoid internal distortions of the economy.

${ }^{10}$ Greenspan, op.cit.

${ }^{11}$ Western economists emphasize the economic distortions associated with inflation. Chinese policymakers are probably more concerned with the political consequences. China already faces political difficulties associated with downsizing employment in the SOE sector and absorbing surplus labor from the agrarian sector. Inflation exacerbates these problems since its costs hit the rural poor hard. The last major political troubles in China - Tiananmen Square, 1989 - occurred at a time of rising inflation. Chinese policymakers are likely aware of this, and may fear inflation more for political than economic reasons.

${ }^{12}$ Open market sterilization operations have the central bank selling bonds, thereby draining deposits from the banking system. Such operations can offset expansions of the money supply resulting from defense of the undervalued exchange rate.

${ }^{13}$ Goldstein and Lardy, op.cit.

${ }^{14}$ Another argument put forward by internal contradictionists regarding why China should revalue and cease running massive trade surpluses is that these surpluses are invested in relatively low yielding U.S. treasury bills and represent poor use of resources. The claim is that China would be better off by directing these resources toward internal consumption which would yield a higher welfare return given China's low level of income. See Williamson, J., The Choice of Exchange Rate Regime: The Relevance of International Experience to China's Decision, outline of a lecture at the Central university of Finance and Economics, Beijing, China, September 7, 2004, www.iie.com/publications/papers/williamson1103.htm.

${ }^{15}$ China's partial privatization of the banking system represents a form of managing entry of foreign financial competition. Rather than setting up new foreign banks, which would drain deposits out of existing banks and precipitate a banking crisis, China aims to reform the banking system by selling part ownership in existing banks to foreign firms. The hope is that this will introduce new management and rectify the credit misallocation problem. China will also benefit from the proceeds raised by selling shares, and these proceeds are large because of the franchise value of the Chinese market. All of this is done within existing institutions so that depositors will have no incentive to exit. Two dangers to this strategy are (i) that preventing foreign firms from opening up will shortly become WTO illegal, and (ii) partial privatization may be insufficient to induce real managerial change within China's banks. However, if China doesn't allow real change of managerial control, it is foreigners who will get fleeced since they will have paid a high price for part ownership of banks that turn out to be worthless.

${ }^{16}$ Detailed theoretical and empirical critiques of the export-led growth paradigm, focusing on why it will not work if simultaneously adopted by all developing countries, are provided by Blecker, R.A., The diminishing Returns to Export-Led Growth, paper prepared for the Council of Foreign Relations Working Group on Development, New York, 2000 and Palley, T.I., Export-led Growth: Is There Any Evidence of Crowding-Out?, in Arestis et al. (eds.), Globalization, Regionalism, and Economic Activity, Cheltenham: Edward Elgar, 2003.

${ }^{17}$ Scott, R., U.S.-China Trade, 1989-2003: Impact on Jobs and Industries, Nationally and State-by-State, Report prepared for the U.S.- China Economic and Security Review Commission, Washington D.C., January 2005.

${ }^{18}$ A more complete discussion of the employment implications of the China trade deficit is contained in Palley, T.I., Trade, Employment and Outsourcing: Some Observations on US - China Economic Relations, paper presented at France/ILO Dialogue, "The Internationalization of Employment: A Challenge for a Fair Globalization?” Annecy, France, April 11-12, 2005 and forthcoming.

${ }^{19}$ Bronfenbrenner, K.. and S. Luce, The Changing Nature of Corporate Global Restructuring: The Impact of Production Shifts on Jobs in the U.S., China, and Around the Globe, Report prepared for the U.S.- China Economic and Security Review Commission, Washington D.C., October 2004.

${ }^{20}$ Blecker, R.A., The Economic Consequences of Dollar Appreciation for U.S. Manufacturing Profits and Investment: A Time Series Analysis, Paper presented at the Post Keynesian Conference, University of Missouri, Kansas City, June 26-29, 2004, and Exchange Rates in North America: Effects of the Overvalued Dollar on Domestic U.S. Manufacturing and Implications for Canada and Mexico, paper presented for the conference "Can Canada and Its NAFTA Partners Conduct Independent Macroeconomic Policies in a Globalized World?” University of Ottawa, Ottawa, Canada, September 20-21, 2002. 
${ }^{21}$ U.S. real fixed non-residential investment peaked at \$1,232.1 billion in 2000 and in 2004 was \$1,228.6 billion. The fact that investment remains below its previous peak level is significantly due to the problems of manufacturing, and these problems can be linked to China.

${ }^{22}$ The arguments about consumer demand leakage and investment profitability apply to other East Asian countries running trade surpluses with the United States.

${ }^{23}$ Much is made of China as an engine of demand growth, particularly with regard to Japan's economic recovery. However, China's internal demand growth is significantly derived from the prosperity generated by exporting to the U.S. economy. In this sense, the U.S. economy is the ultimate source of demand growth, and this demand growth is then multiplied in the global economy with China being an important participant in the multiplier process.

${ }^{24}$ The U.S. trade deficit debate evokes competing theoretical explanations that cannot be tackled in the current paper. Essentially, there are two positions. One position is that the deficit is due to inadequate U.S. saving. A second position is that it is due to severe relative international price misalignments in conjunction with export-led growth. The former view calls for the U.S. to reduce spending and increase saving. The latter view calls for major international relative price realignments and a shift away from export-led growth. This will cause expenditure switching in the U.S. but total spending will remain unchanged. This paper implicitly adopts the second position.

${ }^{25}$ The MFA ended on 1 January 2005.

${ }^{26}$ Private conversations with Chinese policy advisers indicate that the Chinese government understands the national security dangers of export-led growth that relies excessively on a single market (the U.S.). However, the government does not yet appear to have considered the economic dangers resulting from limits to export-led growth.

${ }^{27}$ This raises the question of whether China and other trade surplus countries can keep funding the U.S. consumer indefinitely. The answer is no. This is because the funding is delivered via U.S. banks, and U.S. banks will only make loans to U.S. consumers as long as they believe they will be repaid. The constraint on the system is therefore not the willingness of surplus countries to lend, but rather the availability of good borrowers to lend to.

${ }^{28}$ Palley provides an exploratory analysis of the types of policies needed to develop the demand side. Unlike conventional Keynesian economics, the focus is not on increasing individual components of AD. Instead, it is on establishing an income generation and production process that ensures income gets into the hands of those who will spend it, and encouraging production of needed goods that have high domestic employment and expenditure multipliers. This can be termed "structural Keynesianism" and contrasts with conventional "demand side Keynesianism.” Palley, T.I., A New Development Paradigm: Domestic Demand-Led Growth, Foreign Policy in Focus, September 2002, http://www.fpif.org/. Also published in After Neo-liberalism: Economic Policies That Work for the Poor, in Jacobs, Weaver and Baker (eds.), New Rules for Global Finance, Washington, DC, 2002.

${ }^{29}$ The 15 - 40 percent range is based on the broadly held consensus that the renminbi is undervalued against the dollar by some amount in this range. See Fair Currency Alliance, Experts Agree: China's Currency is Undervalued, Brief No. 2, Washington, D.C., June 28, 2004.

${ }^{30}$ Inflation is a political threat because it risks creating discontent among groups, especially the peasant class, that are disproportionately adversely impacted by inflation.

31 There are many proposals for how a new Bretton Woods coordinated exchange rate system could work. These include Bergsten, C.F., O. Davanne, and P. Jacquet, The Case for Joint Management of Exchange rate Flexibility, Policy Brief 99-9, Institute for International Economics, Washington, DC, 1999, www.iie.com/publications/papers/wp/1999/99-9.htm.; Blecker, R.A., Taming Global Finance: A Better Architecture for Growth and Equity, Economic Policy Insitute, Washington, DC, 1999; Grieve Smith, J., A New Bretton Woods: Reforming the Global Financial System, in Michie and Grieve Smith (eds.), Global Instability: The Political Economy of World Economic Governance, Routledge: London, 1999; Williamson, J., Crawling Bands or Monitoring Bands: How to Manage Exchange Rates in a World of Capital Mobility, Policy Brief 99-3, Institute for International Economics, Washington, DC, 1999, www.iie.com/publications/pb/pb99-3.htm; Weller, C., and Singleton, L., Reining in Exchange Rates: A Better Way to Stabilize the Global Economy, Briefing Paper \#131, Economic Policy Institute, Washington, DC, September 2002.; Palley, T.I., Beyond the Over-valued Dollar: A New Agenda to Avoid Future Dollar Misalignments, unpublished policy discussion paper, Washington, D.C., December 2003. 
${ }^{32}$ Economics ignores demand-side considerations owing to its domination by classical general equilibrium economics that emphasizes Say's law, the claim that supply creates its own demand

33 The case for asset based reserve requirements is outlined in Palley. Such a system can be contrasted with the current system which is liability based. See Palley, T.I., Asset Based Reserve Requirements:

Reasserting Domestic Monetary Control in an Era of Financial Innovation and Instability, Review of Political Economy, 16 (January 2004), 43 - 58.

${ }^{34}$ For neo-classicals, labor markets set wages such that there is full-employment, and income distribution is a by-product that has no consequence for full-employment. For Keynesians, full-employment requires an appropriate level of $\mathrm{AD}$, and the distribution of income is a key parameter impacting $\mathrm{AD}$.

${ }^{35}$ Palley, T.I., Labor Standards, Democracy and Wages: Some Cross-country Evidence,” Journal of International Development, 17 (2005), p.1 - 16. 